\title{
Gene expression in Pseudomonas aeruginosa swarming motility
}

\author{
Julien Tremblay, Eric Déziel ${ }^{*}$
}

\begin{abstract}
Background: The bacterium Pseudomonas aeruginosa is capable of three types of motilities: swimming, twitching and swarming. The latter is characterized by a fast and coordinated group movement over a semi-solid surface resulting from intercellular interactions and morphological differentiation. A striking feature of swarming motility is the complex fractal-like patterns displayed by migrating bacteria while they move away from their inoculation point. This type of group behaviour is still poorly understood and its characterization provides important information on bacterial structured communities such as biofilms. Using GeneChip ${ }^{\oplus}$ Affymetrix microarrays, we obtained the transcriptomic profiles of both bacterial populations located at the tip of migrating tendrils and swarm center of swarming colonies and compared these profiles to that of a bacterial control population grown on the same media but solidified to not allow swarming motility.

Results: Microarray raw data were corrected for background noise with the RMA algorithm and quantile normalized. Differentially expressed genes between the three conditions were selected using a threshold of 1.5 $\log _{2}$-fold, which gave a total of 378 selected genes (6.3\% of the predicted open reading frames of strain PA14). Major shifts in gene expression patterns are observed in each growth conditions, highlighting the presence of distinct bacterial subpopulations within a swarming colony (tendril tips vs. swarm center). Unexpectedly, microarrays expression data reveal that a minority of genes are up-regulated in tendril tip populations. Among them, we found energy metabolism, ribosomal protein and transport of small molecules related genes. On the other hand, many well-known virulence factors genes were globally repressed in tendril tip cells. Swarm center cells are distinct and appear to be under oxidative and copper stress responses.

Conclusions: Results reported in this study show that, as opposed to swarm center cells, tendril tip populations of a swarming colony displays general down-regulation of genes associated with virulence and up-regulation of genes involved in energy metabolism. These results allow us to propose a model where tendril tip cells function as «scouts» whose main purpose is to rapidly spread on uncolonized surfaces while swarm center population are in a state allowing a permanent settlement of the colonized area (biofilm-like).
\end{abstract}

\section{Background}

Pseudomonas aeruginosa is a ubiquitous Gram-negative rod-shaped bacterium responsible for many infections among immunocompromised hosts, burned patients and individuals suffering from cystic fibrosis. Besides wellknown swimming and twitching motilities, this bacterium is capable of another type of migration called swarming. This complex type of motility is usually defined as a rapid and coordinated translocation of a bacterial population across a semi-solid surface (See additional file 1 (movie)) [1,2]. In addition to flagella,

* Correspondence: eric.deziel@iaf.inrs.ca

INRS-Institut Armand-Frappier, Laval (Québec), H7V 1B7, Canada swarming of $P$. aeruginosa requires the release of two exoproducts, rhamnolipids (RLs) and 3-(3-hydroxyalkanoyloxy)alkanoic acids (HAAs), which act as wetting agents and chemotactic-like stimuli [3-6]. The best studied bacterial social behaviour is the formation of attached communities called biofilms. Besides playing a role in swarming motility, RLs and HAAs are also implicated in many aspects of biofilm development [7-9]. Interestingly, swarmer cells of a range of bacteria, including $P$. aeruginosa and Salmonella typhimurium, display enhanced resistance to a variety of antibiotics $[10,11]$, a well-known feature of the biofilm way of life. 
A complex relationship exists between swarming motility and biofilm development [12-15].

A striking feature of $P$. aeruginosa colonies displaying swarming motility is the formation of complex dendritic, fractal-like patterns. Little is known about the gene regulation of the different bacterial subpopulation comprised in a swarming colony. Recently Overhage and coworkers [16] presented a microarray analysis in which a swarmer cell population harvested at the edge of a swarming colony migrating front was compared with broth cultured bacteria. Their data showed that swarm edge cells exhibited up-regulation of genes associated with virulence (e.g. Type III secretion system, extracellular proteases and iron transport) compared with cells cultured in broth.

Besides $P$. aeruginosa, the other bacterial species for which a transcriptomic study of the swarming state has been reported are Salmonella typhimurium [17], Sinorhizobium meliloti [18], and Proteus mirabilis [19]. In their experimental design, Wang et al., (2006) compared entire bacterial colonies grown on swarm medium to cells grown on hard surface not allowing swarming using broth culture for control [17]. They pointed out differentially expressed genes specific to the swarming motility of Salmonella and also determined that the expression of many genes associated with type III secretion, LPS synthesis and iron metabolism was surface-specific and not specifically associated with swarming. Very recently, Nogales et al., (2010) reported the transcriptome of Sinorhizobium meliloti grown on a semi-solid surface. One of their conclusions was that rhizobactin and iron metabolism genes play an important role in swarming motility of this bacterium [18]. The swarming transcriptome of Proteus mirabilis was also recently established [19]. Swarming motility in this bacterium displays concentric circles radiating from an inoculating point formed by successive swarming and consolidation phases and is quite different from what is observed in $P$. aeruginosa. The authors reported that flagellar genes were highly up-regulated in both swarming and consolidation cells compared to cells cultured in broth. Interestingly, comparison of these two phases revealed that only 9 genes were up-regulated during the swarm extension process.

Here we further dissect the whole-genome transcriptomic profile of $P$. aeruginosa swarming motility by comparing gene expression between different bacterial populations localized: 1) at the tip of migrating swarming tendrils, 2) at the center of a swarming colony, and 3) cultured in exactly the same growth conditions except for a harder surface not allowing this type of motility, as control.

\section{Methods}

\section{Bacteria}

This study was performed with $P$. aeruginosa strain PA14. Bacteria from frozen stocks were typically grown at $37^{\circ} \mathrm{C}$ in Tryptic Soy Broth (TSB) (Difco) in a rotary shaker. For swarming assays, overnight cultures were diluted in PBS to the desired $\mathrm{OD}_{600}$.

\section{Motility assays}

Swarming motility assays were performed as previously described [20]. Medium M9DCAA [20 $\mathrm{mM} \mathrm{NH}_{4} \mathrm{Cl} ; 12$ $\mathrm{mM} \mathrm{Na}_{2} \mathrm{HPO}_{4} ; 22 \mathrm{mM} \mathrm{KH} \mathrm{PO}_{4} ; 8.6 \mathrm{mM} \mathrm{NaCl} ; 1 \mathrm{mM}$ $\mathrm{MgSO}_{4} ; 1 \mathrm{mM} \mathrm{CaCl} 2 \mathrm{H}_{2} \mathrm{O} ; 11 \mathrm{mM}$ dextrose; $0.5 \%$ casamino acids (Difco)] was solidified with $0.5 \%$ Bactoagar (Difco) and dried for 60 min under laminar flow in two rows following the length axis of the laminar cabinet. Control non-swarming plates were identically prepared but instead dried for $240 \mathrm{~min}$. All plates were inoculated at their center with $5 \mu \mathrm{L}$ of cell suspension $\left(\mathrm{OD}_{600}=3.0\right)$ and incubated at $30^{\circ} \mathrm{C}$.

\section{Sample preparation for microarray hybridization}

Actively migrating cells were harvested from the tip of migrating tendrils of swarming colonies $12 \mathrm{hrs}$ postinoculation by pipeting $8 \mu \mathrm{L}$ of RNAlater (Qiagen) on the edge of a given tendril. Cells were resuspended by robustly pipeting back and forth while slightly inclining the Petri dish and were directly transferred into a 1.5 $\mathrm{mL}$ microtube kept on dry ice. An average of eight tendril migrating fronts per plate was harvested, with twenty plates for each replicate. Cells localized in the center of swarming colonies were harvested using a hole-cutter of $1 \mathrm{~cm}$ diameter and transferred into a clean Petri dish. Cells adhering to the agar plugs were then collected by vigorously pipeting back and forth 1 $\mathrm{mL}$ of RNAlater and transferred into a $1.5 \mathrm{~mL}$ microtube on dry ice. Ten swarm centers were sampled for each replicate. Non-swarming colonies were harvested by vigorously pipeting back and forth $1 \mathrm{~mL}$ of RNAlater directly on bacteria and were transferred into a $1.5 \mathrm{~mL}$ microtube kept on dry ice. Ten non-swarming colonies were use for each replicate.

RNA was extracted using the RiboPure ${ }^{\text {tw }}$ kit (Ambion). All manipulations were performed according to the manufacturer's instruction. RNA purity was assessed by spectrophotometry (NanoDrop ND-1000). Samples showing ratios of $A_{260} / A_{280}$ and $A_{260} / 230$ superior to 2.0 were selected. RNA quality was then assessed with a Bioanalyzer 2100 (Agilent Technologies). Samples having a RIN of 8.9 and greater were kept.

To maximize cDNA synthesis yield, reverse transcription was performed twice with $6 \mu \mathrm{g}$ of purified RNA for each replicate (total of $12 \mu \mathrm{g} /$ replicate) using random hexamer primers (Invitrogen) and Superscript II reverse transcriptase (Invitrogen). GeneChip ${ }^{\circ}$ Eukaryotic Poly-A RNA Control Kit (Affymetrix) was integrated in each sample for quality control for the hybridization process. Thermocycler routine was performed according to 
Affymetrix's guidelines. RNA was eliminated with a $\mathrm{HCl} / \mathrm{NaOH} 1 \mathrm{~N}$ treatment and $\mathrm{cDNA}$ was purified with the MinElute PCR Purification Kit (Qiagen). Resulting cDNA was digested with DNaseI (Roche) to give fragments between 50 and 200 bases. Samples were tagged with Biotin with the GeneChip DNA Labeling Reagent (Affymetrix) according to the manufacturer's instructions. Quality control of biotin tagging was performed with a gel-shift assay using the ImmunoPure NeutrAvidin Protein (Pierce chemicals) and SybrGold (Invitrogen) for revelation.

\section{Microarray hybridization and data analysis}

Hybridizations were performed at the Genome Québec Innovation Centre (McGill University, Montréal, Canada). Raw data were corrected for background using the RMA algorithm and quantile normalization [21]. Expression levels obtained from three replicates for each condition were compared using the FlexArray 1.3 software [22]. Only genes showing a $p$-value $<0.05$ using the Empirical Bayes (Wright and Simon) algorithm were considered for data analysis. Since the RMA algorithm decreases the false positive rate and compresses the fold change, a 1.5-fold change cut-off value was used for determination of the differentially expressed genes [21]. Functional classification and over-representational analysis were performed using the PseudoCAP functional classes http://www.pseudomonas.com[23]. Expression data of all differentially expressed genes is available in additional file 2 .

\section{qRT-PCR}

Quantitative real-time PCR was performed using qScript $^{\text {th }}$ One-Step SYBR Green kit (Quanta Bioscience) and a RotorGene 6000 thermocycler (Corbett). Primers were designed to give products between 80 and $150 \mathrm{bp}$. The $\operatorname{nadB}$ gene was used as a housekeeping control. Each qRT-PCR run was done in triplicate and for each reaction, the calculated threshold cycle $(\mathrm{Ct})$ was normalized to the $C t$ of $n a d B$ amplified from the corresponding sample. The fold-change was calculated using the $2^{-\Delta \Delta \mathrm{Ct}}$ method [24]. Sequences of primers used for qRT-PCR analysis are available in additional file 3.

\section{Results and Discussion}

Experimental design to identify differentially expressed genes in a $P$. aeruginosa swarming colony - significant transcriptional changes

Previous reports on swarming motility of $P$. aeruginosa showed that this social phenomenon relies on the expression of many genes [25-27]. These studies presented genes that are essential to swarming motility by screening transposon mutant libraries. This approach has provided precious insights but no information on the expression of genes involved in this multicellular behavior. The only published transcriptomic study on $P$. aeruginosa swarming motility was performed by Overhage and coworkers [16]. They reported that many genes associated with virulence were overexpressed at the swarming migration front compared to cells cultured in broth. However, because of the nature of their control condition (i.e. broth suspended cells), results reported in that study essentially gave information on transcriptional differences between surface and broth lifestyles.

Therefore, to further understand the complexity of $P$. aeruginosa swarming migration, microarrays gene expression profiles of bacterial populations localized at the tip of swarming tendrils and swarm centers were established using for control bacteria grown in the same culture conditions but on plates dried longer to prevent swarming motility [20]. Analysis of three independent experiments for each three conditions reveals a total of 378 differentially expressed genes $(p<0.05$ by Empirical Bayes statistical test) using a threshold of $+/-1.5$ fold $\left(\log _{2}\right)$ (table 1). These differently expressed genes are obtained by comparing each three conditions to one another: swarm center vs. non-swarming, tendril tip vs. non-swarming and tendril edge vs. swarm center. A selection of genes from our analysis is discussed below and presented in Tables 2, 3 and 4. A complete list of all differentially expressed genes is available (see additional file 2).

Pairwise comparisons of differentially expressed genes show that a majority of them were differentially expressed in the tendril tip vs. non-swarming category followed by tendril tip vs. swarm center then swarm center vs. non-swarming, respectively (Table 1). Interestingly, many more genes were repressed in tendril tip bacteria (232) compared to the up-regulated ones (75) in the tendril tip vs. non-swarming category, while 121 genes were down-regulated and 20 up-regulated in tendril tip compared to swarm center. The other category (swarm center vs. non-swarming) showed a more even distribution of up-regulated (45) and down-regulated (43) genes. To further expose their complexity, the

Table 1 Differentially expressed genes by pairwise comparison

\begin{tabular}{lccc}
\hline & $\begin{array}{c}\text { Tendril tip } \\
\text { vs. } \\
\text { non- } \\
\text { swarming }\end{array}$ & $\begin{array}{c}\text { Tendril tip } \\
\text { vs. } \\
\text { swarm } \\
\text { center }\end{array}$ & $\begin{array}{c}\text { Swarm } \\
\text { center } \\
\text { vs. } \\
\text { non- } \\
\text { swarming }\end{array}$ \\
\hline $\begin{array}{l}\text { Genes up-regulated } \\
\begin{array}{l}\text { Genes down- } \\
\text { regulated }\end{array}\end{array}$ & 75 & 20 & 45 \\
Total & 232 & 121 & 43 \\
\hline
\end{tabular}

These three pairwise comparisons represent a total of 378 non-redundant genes. 
Table 2 Selected genes up-regulated in tendril tip cells

\begin{tabular}{|c|c|c|c|}
\hline $\begin{array}{l}\text { Gene } \\
\text { number }\end{array}$ & $\begin{array}{l}\text { Gene } \\
\text { name }\end{array}$ & Product name & $\begin{array}{l}\text { Tip vs. non- } \\
\text { swarming fold } \\
\left.\text { change ( } \log _{2}\right)\end{array}$ \\
\hline
\end{tabular}

Transcriptional regulators

PA0961 $^{2} \quad$ probable cold-shock protein

$\quad 1.5$

PA5403 ${ }^{1} \quad$ probable transcriptional

PA5550 glmR GlmR transcriptional

regulator

Energy metabolism

\begin{tabular}{|c|c|c|}
\hline PA1552 & CCOP1 & probable cytochrome c \\
\hline PA1553 & $\mathrm{ccoO} 1$ & $\begin{array}{l}\text { probable cytochrome c } \\
\text { oxidase subunit }\end{array}$ \\
\hline PA1554 & $\mathrm{ccoN1}$ & $\begin{array}{l}\text { probable cytochrome } \\
\text { oxidase subunit (cbb3-type) }\end{array}$ \\
\hline PA4133² & & $\begin{array}{l}\text { cytochrome c oxidase } \\
\text { subunit (cbb3-type) }\end{array}$ \\
\hline PA4429 & petC & $\begin{array}{l}\text { probable cytochrome c1 } \\
\text { precursor }\end{array}$ \\
\hline PA4430 & petB & probable cytochrome b \\
\hline PA4431 & $\operatorname{pet} A$ & probable iron-sulfur protein \\
\hline PA5553 & $\operatorname{atpC}$ & ATP synthase epsilon chain \\
\hline PA5554 & $\operatorname{atpD}$ & ATP synthase beta chain \\
\hline PA5555 & $\operatorname{atpG}$ & ATP synthase gamma chain \\
\hline PA5556* & $\operatorname{atpA}$ & ATP synthase alpha chain \\
\hline PA5557* & atpH & ATP synthase delta chain \\
\hline PA5558* & $a t p F$ & ATP synthase B chain \\
\hline PA5559* & $\operatorname{atp} E$ & ATP synthase $C$ chain \\
\hline PA5560 & $a t p B$ & ATP synthase A chain \\
\hline PA5561* & atpl & ATP synthase protein I \\
\hline
\end{tabular}

Protein secretion/export apparatus

$\begin{array}{llll}\text { PA3821 } & \text { secD } & \text { secretion protein SecD } & 1.6 \\ \text { PA3820 } & \text { secF } & \text { secretion protein SecF } & 1.6 \\ \text { PA5568 } & \text { yidC } & \begin{array}{l}\text { Preprotein translocase } \\ \text { subunit YidC }\end{array} & 1.7\end{array}$

Transport of small molecules

\begin{tabular}{|c|c|c|}
\hline PA3531 ${ }^{1}$ & $b f r B$ & bacterioferritin \\
\hline PA4616 ${ }^{1}$ & & $\begin{array}{l}\text { probable c4-dicarboxylate- } \\
\text { binding protein }\end{array}$ \\
\hline PA3187 & gltK & $\begin{array}{l}\text { probable ATP-binding } \\
\text { component of ABC } \\
\text { transporter }\end{array}$ \\
\hline PA3188 & gltG & $\begin{array}{l}\text { probable permease of } A B C \\
\text { sugar transporter }\end{array}$ \\
\hline PA4628 & lys $P$ & lysine-specific permease \\
\hline PA5479 & $g / t P$ & proton-glutamate symporter \\
\hline PA0782 ${ }^{3}$ & putA & proline dehydrogenase \\
\hline PA0783 ${ }^{1}$ & putP & $\begin{array}{l}\text { sodium/proline symporter } \\
\text { PutP }\end{array}$ \\
\hline PA4770 ${ }^{1}$ & $\| d P$ & L-lactate permease \\
\hline
\end{tabular}

Table 2 Selected genes up-regulated in tendril tip cells (Continued)

\begin{tabular}{|c|c|c|c|}
\hline \multicolumn{4}{|c|}{$\begin{array}{l}\text { Translation, post-translational modification, } \\
\text { degradation }\end{array}$} \\
\hline PA0579 & $\operatorname{rps} U$ & 30 ribosomal protein S21 & 1.5 \\
\hline PA2619 & $\operatorname{infA}$ & initiation factor & 1.8 \\
\hline PA2851 & efp & $\begin{array}{l}\text { translation elongation factor } \\
P\end{array}$ & 1.8 \\
\hline PA3655 ${ }^{1}$ & tsf & elongation factor Ts & 1.7 \\
\hline PA3742 & $r p / s$ & $50 S$ ribosomal protein L19 & 1.8 \\
\hline PA4255 & rpmC & $50 S$ ribosomal protein L29 & 1.7 \\
\hline PA4432 ${ }^{1}$ & rpsl & 30 S ribosomal protein $\$ 9$ & 1.8 \\
\hline PA4567 & rpmA & $50 S$ ribosomal protein L27 & 1.5 \\
\hline PA4672 & & peptidyl-tRNA hydrolase & 1.7 \\
\hline PA5049 & rpmE & $50 S$ ribosomal protein L31 & 1.6 \\
\hline \multicolumn{4}{|c|}{$\begin{array}{l}\text { ': Genes up-regulated in tendril tip vs. NS and up-regulated in tendril tip vs. } \\
\text { center. }\end{array}$} \\
\hline \multicolumn{4}{|c|}{$\begin{array}{l}\text { : Genes up-regulated in tendril tip vs. NS and up-regulated in swarm center } \\
\text { vs. NS. } \\
\text { 3. putA was significantly up-regulated in tip cells vs. swarm center, but not tip } \\
\text { cells vs. NS. }\end{array}$} \\
\hline \multicolumn{4}{|c|}{$\begin{array}{l}\text { *: Genes up-regulated in tendril tip vs. NS only and expressed more than } 1.3 \\
\log _{2} \text {-fold). Genes kept in our analysis since they are part of an operon or in } \\
\text { certain cases, a pertinent cluster. }\end{array}$} \\
\hline
\end{tabular}

expression data have been scattered in a Venn diagram (additional file 4). Genes ID and fold-change $\left(\log _{2}\right)$ values can be found in additional file 2 (excel file) under the summary tab.

The most striking aspect of the expression data overview is that an important majority of differently expressed genes are down-regulated in the tendril tip populations compared to the non-swarming control and to the swarm center. Furthermore, there are far fewer genes differently expressed between the swarm center and non-swarming control that there are between tendril tip and non-swarming control. This suggests that swarm center cells are metabolically closer to nonswarming condition cells than to tendril tip cells. Interestingly, the few differently expressed genes present in the swarm center vs. non-swarming category in general present a higher fold-change value that those observed in the tendril tip vs. non-swarming category.

Figure 1 presents an over-representation analysis of gene expression data based on their PseudoCAP function classes [23] in function of class category \%. We can see that many genes belonging to the Secreted factors (toxins, enzymes, alginate) and Carbon compound catabolism categories are down-regulated in tendril tip cells. On the other hand, swarming tendril tip populations up-regulate genes in the Translational, post-translational modification, degradation, Non-coding RNA gene, Cell division and Transcription, RNA processing and degradation categories. The Energy metabolism category is 
Table 3 Selected genes down-regulated in tendril tip cells

\begin{tabular}{|c|c|c|c|}
\hline $\begin{array}{l}\text { Gene } \\
\text { number }\end{array}$ & $\begin{array}{l}\text { Gene } \\
\text { name }\end{array}$ & Product name & $\begin{array}{l}\text { Tip vs. non- } \\
\text { swarming fold } \\
\text { change ( }\left(\log _{2}\right)\end{array}$ \\
\hline
\end{tabular}

Adaptation, Protection

PA2147 katE catalase HPII

\section{Chemotaxis}

PA1930' mcpS probable chemotaxis transducer PA2788 ${ }^{2} \quad$ probable chemotaxis transducer

PA4915 probable chemotaxis transducer

\section{Biosynthesis of cofactors, prosthetic groups} and carriers

PA1986 biosynthesis protein A biosynthesis protein $B$

PA1987 pqaC pyrroloquinoline quinone biosynthesis protein $C$

PA1988² pqqD pyrroloquinoline quinone biosynthesis protein $\mathrm{D}$

PA1989 pq9E pyrroloquinoline quinone biosynthesis protein $\mathrm{E}$

\section{Energy metabolism}

PA0105² COXB cytochrome c oxidase, subunit II

PA0106 ${ }^{2}$ COXA cytochrome c oxidase, subunit I

$\mathrm{PA0107}^{2} \quad$ conserved hypothetical protein

PA0108 ${ }^{2}$ colll cytochrome c oxidase, subunit III

PA1175² napD NapD protein of periplasmic

nitrate reductase

$\mathrm{PA} 1177^{2}$ napE periplasmic nitrate reductase protein NapE

PA1931 probable ferredoxin

PA21532 glgB 1,4-alpha-glucan branching

$$
\text { enzyme }
$$

PA2165 2 probable glycogen synthase

PA2290² gcd glucose dehydrogenase

PA3416 probable pyruvate

dehydrogenase E1 component, beta chain

PA3417

$$
\text { probable pyruvate }
$$

dehydrogenase E1 component, alpha subunit

PA5427 adhA alcohol dehydrogenase

\section{Secreted Factors (toxins, enzymes, alginate)}

$\begin{array}{lll}\text { PA2570 } & \text { lecA } & \text { LecA } \\ \text { PA1148 } & \text { toxA } & \text { exotoxin A precursor } \\ \text { PA1245 } & \text { aprX } & \text { Hypothetical protein } \\ \text { PA1246 } & \text { aprD } & \begin{array}{l}\text { alkaline protease secretion } \\ \text { protein AprD }\end{array} \\ \text { PA1247 aprE } & \begin{array}{l}\text { alkaline protease secretion } \\ \text { protein AprE }\end{array}\end{array}$

Table 3 Selected genes down-regulated in tendril tip cells

\begin{tabular}{|c|c|c|c|}
\hline PA1249 & $a p r A^{*}$ & $\begin{array}{l}\text { alkaline metalloproteinase } \\
\text { precursor }\end{array}$ & -1.4 \\
\hline PA1250² & aprl & alkaline proteinase inhibitor Aprl & -1.9 \\
\hline $\mathrm{PA} 1871^{2}$ & las $A$ & LasA protease precursor & -3.2 \\
\hline PA2939 ${ }^{3}$ & рерB & Aminopeptidase & -1.5 \\
\hline PA1130 & $r h / C$ & rhamnosyltransferase 2 & -1.5 \\
\hline PA1131 & & $\begin{array}{l}\text { probable major facilitator } \\
\text { superfamily (MFS) transporter }\end{array}$ & -1.6 \\
\hline PA3478 & $r h / B$ & rhamnosyltransferase 1 & -2.3 \\
\hline PA3479² & $r h / A$ & HAA synthase & -2.0 \\
\hline $\mathrm{PA} 2255^{3}$ & $p \vee c B$ & $\begin{array}{l}\text { paerucumarin biosynthesis } \\
\text { protein } P v c B\end{array}$ & -1.7 \\
\hline PA2402 & pvdl & $\begin{array}{l}\text { non-ribosomal peptide synthase } \\
\text { Pvdl }\end{array}$ & -1.5 \\
\hline PA2406 ${ }^{3}$ & & hypothetical protein & -1.9 \\
\hline PA2408 ${ }^{3}$ & & $\begin{array}{l}\text { probable ATP-binding } \\
\text { component of ABC transporter }\end{array}$ & -1.7 \\
\hline PA2411 ${ }^{2}$ & & probable thioesterase & -1.7 \\
\hline PA2412 ${ }^{2}$ & & hypothetical protein & -1.6 \\
\hline PA2413² & pvdH & $\begin{array}{l}\text { L-2,4-diaminobutyrate:2- } \\
\text { ketoglutarate 4-aminotransferase, } \\
\text { PvdH }\end{array}$ & -2.0 \\
\hline PA2424² & $p v d L$ & $\begin{array}{l}\text { Predicted non-ribosomal peptide } \\
\text { synthetase PvdL }\end{array}$ & -2.3 \\
\hline PA2425 & $p v d G$ & Thioesterase PvdG & -1.8 \\
\hline PA4222 & pchl & $\begin{array}{l}\text { probable ATP-binding } \\
\text { component of ABC transporter }\end{array}$ & -2.0 \\
\hline PA4223² & pchH & $\begin{array}{l}\text { probable ATP-binding } \\
\text { component of ABC transporter }\end{array}$ & -2.0 \\
\hline PA4224² & pchG & $\begin{array}{l}\text { pyochelin biosynthesis protein } \\
\text { PchG }\end{array}$ & -2.3 \\
\hline PA4225 2 & $p c h F$ & pyochelin synthetase & -2.4 \\
\hline PA4226 ${ }^{2}$ & pchE & $\begin{array}{l}\text { dihydroaeruginoic acid } \\
\text { synthetase }\end{array}$ & -2.2 \\
\hline PA4228 & $p c h D$ & $\begin{array}{l}\text { pyochelin biosynthesis protein } \\
\text { PchD }\end{array}$ & -1.7 \\
\hline PA4229² & pchC & $\begin{array}{l}\text { pyochelin biosynthetic protein } \\
\text { PchC }\end{array}$ & -1.8 \\
\hline PA4230 & $p c h B$ & $\begin{array}{l}\text { salicylate biosynthesis protein } \\
\text { PchB }\end{array}$ & -1.8 \\
\hline PA4231 & $p c h A$ & $\begin{array}{l}\text { salicylate biosynthesis } \\
\text { isochorismate synthase }\end{array}$ & -1.8 \\
\hline
\end{tabular}
(Continued)

\section{Transcription factors}

$\begin{array}{llll}\text { PA2259 } & \text { ptxS } & \text { transcriptional regulator PtxS } & -2.0 \\ \text { PA0471 } & \text { fiuR } & \text { Anti-sigma factor for Fiul } & -1.9 \\ \text { PA0472 } & \text { fiul } & \text { sigma-70 factor, ECF subfamily } & -1.5 \\ \text { PA1300 } & & \text { sigma-70 factor, ECF subfamily } & -1.9 \\ \text { PA2895 } & & \text { Anti-sigma factor for PA2896 } & -1.9 \\ \text { PA2896 } & \text { sigma-70 factor, ECF subfamily } & -1.8 \\ \text { PA1912 } & \text { sigma-70 factor, ECF subfamily } & -1.8 \\ \text { PA2312 } & \text { probable transcriptional regulator } & -1.7 \\ \text { PA5116 } & \text { probable transcriptional regulator } & -1.6\end{array}$


Table 3 Selected genes down-regulated in tendril tip cells (Continued)

\begin{tabular}{|c|c|c|}
\hline \multicolumn{3}{|c|}{ Two-component regulatory systems } \\
\hline PA3346 & $\begin{array}{l}\text { probable two-component } \\
\text { response regulator }\end{array}$ & -1.6 \\
\hline PA1243 & $\begin{array}{l}\text { probable sensor/response } \\
\text { regulator hybrid }\end{array}$ & -2.2 \\
\hline PA2177 & $\begin{array}{l}\text { probable sensor/response } \\
\text { regulator hybrid }\end{array}$ & -1.8 \\
\hline \multicolumn{3}{|c|}{$\begin{array}{l}\text { ': Genes down-regulated in tendril tip vs. NS and down-regulated in swarm } \\
\text { center vs. NS. }\end{array}$} \\
\hline \multicolumn{3}{|c|}{$\begin{array}{l}\text { 2: Genes down-regulated in tendril tip vs. NS and down-regulated in tips vs. } \\
\text { swarm center. }\end{array}$} \\
\hline \multicolumn{3}{|c|}{ 3: Genes down-regulated in tendril tip vs. swarm center only. } \\
\hline
\end{tabular}

also disregulated in swarm tip cells. Also noteworthy is that the tendril tip vs. non-swarming category shows a majority of genes down-regulated in membrane proteins, transport of small molecules, two-component regulatory systems, biosynthesis of cofactors, prosthetic groups and carriers and transcriptional regulators. It is to be noted that no genes coding for products of the flagellar apparatus are seen in our analysis. This agrees with our microscopic observations of PA14 tendril tip and swarm center cells, which always show single flagella-equipped bacteria (additional file 5).

\section{Validation of microarray results by qRT-PCR}

Validation of microarray data was performed using qRTPCR. Eight genes in tendril tip vs. non-swarming (1 up-, 4 down-regulated and 3 non-differentially expressed genes) and swarm center vs. non-swarming (3 up-, 2 down-regulated and 3 non-differentially expressed genes) were selected for this comparative analysis (Table 5). Expression data of microarray and qRT-PCR are plotted in figure 2 and demonstrate an excellent concordance between the two datasets. Pearson correlation values scored 0.97 and 0.98 for center vs. non-swarming and vs. tendril tip, respectively.

\section{Genes positively regulated in tendril tip cells}

Among the genes up-regulated in tendril tip bacterial population are found a high number of genes involved in the energy metabolism functional class. These genes' products include many cytochromes (PA1552-PA4429PA4430) and cytochrome oxidase subunits (PA1553PA1554-PA4133), which are involved in the production of ATP via the respiratory electron transport chain. We also found the atpIBEFHAGFC cluster coding for the only ATP synthase complex of $P$. aeruginosa. This suggests that fast moving swarmer cells in tendril tips require more energy than non-swarming and swarm center cells.
Table 4 Selected genes up-regulated in swarm center

\begin{tabular}{|c|c|c|c|}
\hline $\begin{array}{l}\text { Gene } \\
\text { number }\end{array}$ & $\begin{array}{l}\text { Gene } \\
\text { name }\end{array}$ & Product name & $\begin{array}{l}\text { Swarm center vs. } \\
\text { non-swarming fold } \\
\text { change }\left(\log _{2}\right)\end{array}$ \\
\hline \multicolumn{4}{|c|}{ Adaptation, Protection } \\
\hline PA0140 ${ }^{1}$ & $a h p F$ & $\begin{array}{l}\text { alkyl hydroperoxide } \\
\text { reductase subunit F }\end{array}$ & 4.5 \\
\hline PA0848 ${ }^{1}$ & & $\begin{array}{l}\text { probable alkyl } \\
\text { hydroperoxide reductase }\end{array}$ & 5.4 \\
\hline PA0849 ${ }^{1}$ & $\operatorname{tr} x B 2$ & thioredoxin reductase 2 & 3.7 \\
\hline PA3287 ${ }^{1}$ & & $\begin{array}{l}\text { conserved hypothetical } \\
\text { protein }\end{array}$ & 4.7 \\
\hline PA4236 ${ }^{1}$ & katA & catalase & 3.4 \\
\hline PA4613 ${ }^{1}$ & katB & catalase & 4.4 \\
\hline \multicolumn{4}{|c|}{ Energy metabolism } \\
\hline PA4133² & & $\begin{array}{l}\text { cytochrome c oxidase } \\
\text { subunit (cbb3-type) }\end{array}$ & 1.6 \\
\hline
\end{tabular}

\begin{tabular}{lll}
\multicolumn{2}{l}{ Hypothetical, unclassified, unknown } \\
PA3237 & hypothetical protein & 5.4 \\
PA3287 & hypothetical protein & 4.7 \\
PA3519 & hypothetical protein & 3.6 \\
PA3520 $^{3}$ & hypothetical protein & 1.8
\end{tabular}

Nucleotide biosynthesis and metabolism

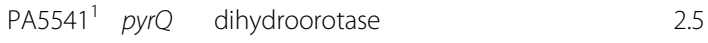

\section{Transcriptional regulators}

$\begin{array}{lll}\text { PA4878 } & & \\ & \text { probable transcriptional }\end{array}$ regulator

Transport of small molecules

PA2322 gntT gluconate permease 2.0

PA3187 ${ }^{2}$ gltK ATP-binding component of $\quad 2.6$

PA3188 ${ }^{2}$ gltG permease of ABC sugar 3.1

PA3189 gltF permease of ABC sugar 2.5

$\begin{array}{lll} & \text { transporter } \\ \text { PA3523 }^{1} \text { mexP } & \text { probable Resistance- } & 4.2\end{array}$

Nodulation-Cell Division

(RND) efflux membrane

fusion protein precursor

PA3920 ${ }^{1}$ cueA copper homeostasis P-type 2.6

$\begin{array}{lll}\text { PA5082 probable binding protein } & 1.5\end{array}$ component of $\mathrm{ABC}$ transporter

': Genes up-regulated in swarm center vs. NS and up-regulated in swarm center vs. tendril tip.

${ }^{2}:$ Genes up-regulated in swarm center vs. NS and up-regulated in tendril tip vs. NS (Table 1).

${ }^{3}$ : Gene up-regulated in swarm center vs. tendril tip only.

Bacterial heme-copper oxidases, such as cytochrome $c$ oxidases, are key components of cellular energy transduction systems and contribute to the establishment of 


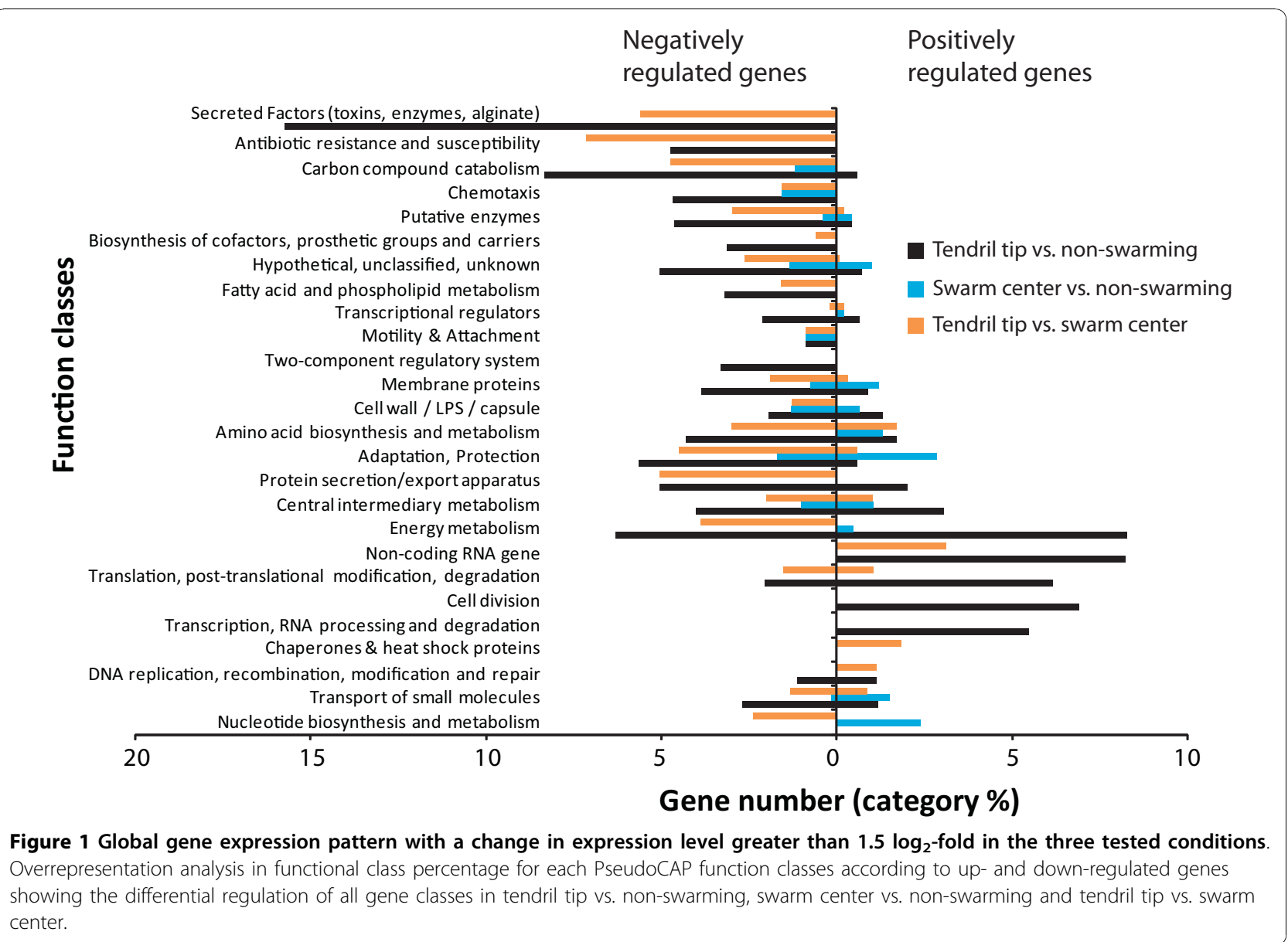

the electrochemical gradient subsequently used for ATP production by the ATP synthases [28]. At the tip of swarming tendrils, PA4429-31 is overexpressed (Table 2 ). This operon shows high similarity to pet $A B C$ (also known as $f b c F B C$ ) encoding for polypeptides of the cytochrome $b c 1$ complex (ubihydroquinone: cytochrome $c$ oxidoreductase) [29]. A third group of cytochromes having a very high affinity for $\mathrm{O}_{2}$ has been described in recent years among proteobacteria, the cytochrome $c b b_{3}$ oxidase [30]. P. aeruginosa contains two ccoNOQP operons (ccoNOQP-1 and ccoNOQP-2) coding for cytochrome $\mathrm{cbb}_{3}$ oxidases (PA1552-PA1554 and PA1555-

Table 5 Genes used for microarray validation with qRT-PCR

\begin{tabular}{|c|c|c|c|c|c|c|}
\hline \multirow{2}{*}{$\begin{array}{l}\text { Gene } \\
\text { number }\end{array}$} & \multirow{2}{*}{$\begin{array}{l}\text { Gene } \\
\text { name }\end{array}$} & \multirow[t]{2}{*}{ Product name } & \multicolumn{2}{|c|}{ MA fold change $\left(\log _{2}\right)$} & \multicolumn{2}{|c|}{ qRT-PCR fold change $\left(\log _{2}\right)$} \\
\hline & & & $\begin{array}{c}\text { Center } \\
\text { vs. } \\
\text { non- } \\
\text { swarming }\end{array}$ & $\begin{array}{c}\text { Tip } \\
\text { vs. } \\
\text { non- } \\
\text { swarming }\end{array}$ & $\begin{array}{c}\text { Center } \\
\text { vs. } \\
\text { non- } \\
\text { swarming }\end{array}$ & $\begin{array}{c}\text { Tip } \\
\text { vs. } \\
\text { non- } \\
\text { swarming }\end{array}$ \\
\hline PA0140 & $a p h F$ & alkyl hydroperoxide reductase subunit F & $\mathrm{A}_{4.5}$ & ${ }^{B} 1.0$ & $\mathrm{~A}_{4.7}$ & ${ }^{\mathrm{B}} 0.7$ \\
\hline PA1130 & $r h / C$ & rhamnosyltransferase 2 & $c_{-0.5}$ & $D_{-1.5}$ & $c_{-0.4}$ & $D_{-2.1}$ \\
\hline PA1553 & ccoO1 & probable cytochrome c oxidase subunit & ${ }^{\mathrm{E}} 0.7$ & $F_{2.1}$ & ${ }^{\mathrm{E}} 0.7$ & $\mathrm{~F}_{1.9}$ \\
\hline PA2158 & & probable alcohol dehydrogenase (Zn-dependent) & $G_{-1.7}$ & $\mathrm{H}_{-4.4}$ & $G_{-1.5}$ & $\mathrm{H}_{-4.7}$ \\
\hline PA2570 & lecA & LecA & '-2.0 & J -4.5 & '-1.5 & J -4.3 \\
\hline PA3187 & & $\begin{array}{l}\text { probable ATP-binding component of ABC } \\
\text { transporter }\end{array}$ & $\mathrm{k}_{2.6}$ & $\mathrm{~L}_{1.5}$ & $\mathrm{~K}_{2.9}$ & $\mathrm{~L}_{1.8}$ \\
\hline PA3478 & $r h / B$ & rhamnosyltransferase chain B & $M_{-0.9}$ & $N_{-}-2.3$ & $M_{-1.4}$ & $N_{-}-2.9$ \\
\hline PA5540 & & Hypothetical protein & O $; 2.0$ & $P_{0.5}$ & $\mathrm{O}_{2.9}$ & $P_{1.0}$ \\
\hline
\end{tabular}

Letters for each value refer to the corresponding points in figure 2 . 


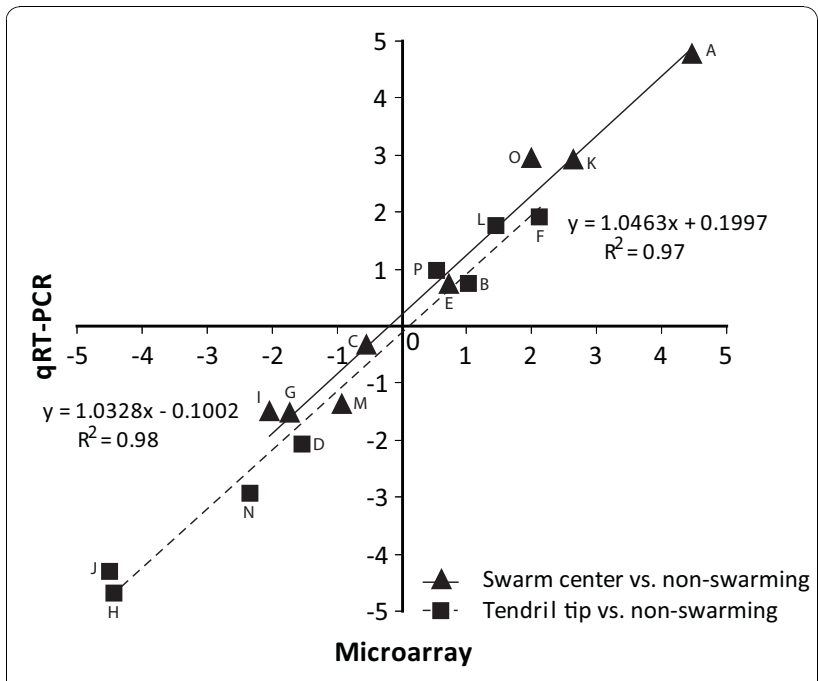

Figure 2 Microarray results validation by qRT-PCR. Mean $\log _{2}$ ratios of the GRT-PCR experiments are plotted against the mean $\log _{2}$ ratios of the microarray experiments. Numbers on the graph refer to genes listed in Table 5.

PA1557, respectively). Intriguingly, ccoNOQP-1, but not ccoNOQP-2, is up-regulated in tendril tip cells (Table 2). Most studies on several bacterial $c b b_{3}$ oxidases have indicated that these enzymes are primarily expressed under oxygen limitation and are critical for respiration in microaerobic conditions. However, the $P$. aeruginosa homologues show different expression patterns depending on oxygen availability [31]: the first operon ( $\mathrm{cco}$ NOQP1) displays higher expression under high oxygen availability while the second one is up-regulated under oxygen-limiting condition [31]. Actually, recent results indicate that Cbb3-1 plays a primary role in aerobic growth irrespective of oxygen concentration; Kawakami et al. (2009) have observed a phase-dependent regulation of $c c 0 N O Q P-1$ expression, with much higher transcription levels in exponential phase compared to stationary phase growth [32].

In the end, our data indicates that two cytochrome $c$ oxidases are specifically induced in tendrils tip cells; they are not differentially regulated in the swarm center and non-swarming conditions. Since the ATP synthase gene cluster is also up-regulated at the tip (Table 2), we conclude that swarming tip cells are highly metabolically active; their elevated energy requirements, presumably mostly for motility purposes, involve elevated $\mathrm{O}_{2}$ consumption.

We also obtained an up-regulation of many ribosomal proteins in tendril tip cells. Ribosomal proteins assist in the assembly and increase the stability of rRNA, without requiring ATP for their action [33]. Synthesis of ribosomal proteins and rRNA is tightly regulated and coordinated so they are never in excess [34]. This, along with the up-regulation of many tRNA genes in tendril tips (see additional file 2), suggests that tip cells display a high protein synthesis rate. Swarming cells of $S$. meliloti were also reported to display an up-regulation of many ribosomal proteins [18].

A number of tendril tip overexpressed genes are involved in the transport of small molecules (Table 2). Among them, $b f r B$ was up-regulated $2.74 \log _{2}$-fold. This gene codes for a bacterioferritin, a protein involved in the controlled storage and release of iron [35] that acts as a buffer against iron overload and deficiency [36]. An investigation of the global transcriptional response of iron-starved cultures of $P$. aeruginosa to iron exposure showed that mRNA levels of $b f r B$ increased significantly when iron was made available, whereas $b f r A$ mRNA levels remained unchanged [37]. Since tendril migrating front cells are colonizing still unpopulated (i.e. iron rich) area, $b f r B$ up-regulation is in agreement with previous findings that $\mathrm{Bfr} B$ is induced by iron-replete conditions while BfrA is constitutively expressed [37,38].

Both the proline and the glutamate symporters (putP and $g l t P$ ) are induced at the swarming tip. In bacteria, glutamate serves as the general amino group donor for amino acid and nucleotide biosynthesis, and may also act as a source of carbon and nitrogen under nitrogenlimiting conditions. In many bacteria, proline is needed as an osmoprotectant in growth environments with high osmotic stress [39]. It is also catabolically converted into glutamate by the product of putA (encoding for a proline dehydrogenase) [40] which was also up-regulated in tip cells. Activation of the lysine permease and genes coding for the GltF-GltG-GltK high-affinity glucose transporter [41] further support a general up-regulation of specific uptake mechanisms in metabolically very active cells located at the tip of swarming tendrils.

Two secretion-related genes, $\sec D$ and $\sec F$, were upregulated in tendril tips. In $E$. coli, SecD/SecF are required for the proton-motive force dependant translocation of proteins [42]. Why only secD and secF and not other sec genes are differentially expressed is elusive at the moment. In E. coli, YidC associates with SecD and $\mathrm{SecF}$ in a preprotein translocase [43]. YidC depletion dissipated proton motive force, notably caused by defects in membrane assembly of both cytochromes and ATPases [44]. The up-regulation of $\sec D \sec F$, and yidC might thus be related to, and a consequence of, the induced cytochrome and ATPase components in swarm tip cells.

\section{Genes negatively regulated in tendril tip cells}

Interestingly, the global picture of expression data shows that most disregulated genes found in our study are actually down-regulated in cells located at tendril tips compared to the non-swarming control (Figure 1A). 
Among them, we found the coxBAC-coll operon encoding for the $a a_{3}$ cytochrome $c$ oxidase [32]. Expression of this operon is up-regulated at the stationary phase, especially by nutrient-limiting conditions: carbon, nitrogen and iron starvation all induce transcription from the cox promoter [32]. Not surprisingly, the stationary-phase sigma factor RpoS is a positive regulator of the cox genes [45]. It is thus perfectly coherent with the model that swarming tip bacteria are highly active cells growing under nutrient-replete conditions.

The entire $p q q$ operon ( $p q q D A B C E)$ coding for pyrroloquinoline quinone (PQQ) was down-regulated in tendril tips. PQQ is one of several quinone derivatives functioning as essential cofactors for a class of enzymes known as quinoproteins [46,47]. For instance, it is the co-factor of the glucose dehydrogenase which catalyses the conversion of glucose to gluconate [47], the first step in the oxidative pathway of glucose utilisation. Interestingly, the $g c d$ (PA2290) gene encoding for the membrane-bound glucose dehydrogenase is also downregulated in tendril tips (Table 3). This would mean that swarming tip cells prefer to uptake and use glucose directly through the phosphorylative pathway to sustain the Entner-Doudoroff pathway. The phosphorylative pathway is thought to be preferred when oxygen is limiting [48]. Explanation to why $p q q$ and gcd are downregulated in tendril tip bacteria remains speculative at the moment: maybe the high respiration rate and high energy consumption at the tip of tendrils can somehow be reflected in reduced $\mathrm{O}_{2}$ availability and switching to the phosphorylative pathway of glucose utilisation.

Genes with chemotaxis-related functions were also found to be down-regulated. PA1930 codes for the soluble chemotaxis transducer McpS that was shown to be localized at cell poles [49]. It was also reported that the $\mathrm{N}$ terminus of McpS carries two putative PAS domains. These domains are present in numerous MCPs involved in light, oxygen and redox sensing [49]. The role of PA2788 and PA4915, two probable chemotaxis transducers is still unknown.

PA2165, coding for a probable glycogen synthase and $\operatorname{glg} B$, encoding a glucan branching enzyme were also both down-regulated in tendril migrating front. These enzymes are involved in building glucose polymeric stocks (i.e. glycogen). This suggests that tendril tip bacteria are not building energy reserves but are instead consuming available carbon sources immediately.

An important observation is that many genes associated with virulence, especially secreted factors, were down-regulated in tendril tips and swarm center vs. non-swarming conditions. The extensive damage caused by $P$. aeruginosa during infections is due to the production of several cell-associated and extracellular virulence factors [50]. Interestingly, the previously published genome-wide transcriptomic study reported that swarming cells of $P$. aeruginosa display enhanced expression of many virulence determinants [16]. For instance, these authors found that genes associated with pyoverdin, pyochelin and phenazine biosynthesis were up-regulated in migrating swarm front compared to broth cultured cells [16]. In contrast, our transcriptomic data indicates that under swarming motility (tendril tip cells) there is a global shutdown of this category of genes.

We did not expect rhlAB and $r h l C$ to be down-regulated in swarm tendril tips since rhamnolipid production is a key factor in P. aeruginosa swarming motility. However, close examination of the expression data actually reveals that rhlAB is more highly expressed in cells from the swarm center than from the tendril tips, suggesting that rhamnolipids are primarily produced from cells at the center of a swarming colony.

Pyochelin ( $p c h I, p c h H, p c h G, p c h F, p c h E, p c h D, p c h C$, $p c h B, p c h A$ ) and pyoverdin ( $p v d I, p v d H, p v d L G$, PA24032410 operon, PA2411, PA2412) synthesis genes were also down-regulated in tendril tip cells. Pyochelin and pyoverdin are the two major siderophores produced by $P$. aeruginosa to acquire iron [51-53]. They chelate iron in the extracellular medium and transport it into the cells via specific outer membrane transporters, FptA for pyochelin [54] and FpvA for pyoverdin [55]. Besides iron, pyochelin also has affinity for other metals such as $\mathrm{Co}^{2+}, \mathrm{Ga}^{3+}$, and $\mathrm{Ni}^{2+}$ [56]. As it is the case with $r h l A B$ and $r h l C$, the $p c h$ and $p v d$ genes were more highly expressed in swarm center compared to tendril tips, possibly because the cellular density in the swarm center is higher and that iron availability is therefore depleted and restricted. Indeed swarming tendrils are moving towards uncolonized areas that are still rich in iron (and other metals and nutrients), thus possibly explaining the down-regulation of siderophore synthesis genes. This is consistent with the above noted up-regulation of the bacterioferritin coding gene $b f r B$ at the tip of tendrils. In addition, we previously demonstrated that rhamnolipids/HAAs diffuse rapidly on a surface $[6,20]$. These surfactant molecules are known to be potent antimicrobials and it is possible that one function of swarm center cells is to produce a quickly diffusing rhamnolipid-rich area protecting the tendril tip bacteria migrating in a hostile environment.

The expression of a number of protease-encoding genes is reduced at the tip of tendrils. Genes las $A$ and PA2939, which respectively encodes for the LasA protease, a 20-kDa staphylolytic enzyme [57], and a secreted aminopeptidase [58] were down-regulated in tendril tip cells. Genes belonging to the alkaline protease synthesis and secretory cluster (aprXaprDaprE, aprA, aprII) were also down-regulated in tendril migrating front cells. The expression of these genes is up-regulated under iron-limiting conditions [59]. 
The two genes $p t x S$ and toxA were also down-regulated in tendrils. PtxS is a transcriptional regulator that controls the expression of toxA [60,61], whose product exotoxin A, like many other bacterial virulence factors, is negatively regulated by iron availability [59,62-64]. Again, this is consistent with tendril tip cells migrating over an uncolonized area where iron resources have not been yet depleted.

The gene coding for the galactophilic lectin LecA was down-regulated at the tendril tips. The product of this gene is an adhesin which has the ability to bind cells together in a biofilm [65]. The individual nature of fast moving swarming cells makes it logical for lecA to be down-regulated under these conditions, to allow cells to freely migrate.

Apart from PA5403 and PA5550 ( $g l m R / g l p R)$ (Table 2), nearly all genes belonging to the transcription factors class were down-regulated in tendril tip populations (Table 3), including a number of ECF sigma factors. GlmR is a regulatory gene involved in amino sugar metabolism. Its inactivation abolished swarming, swimming and twitching motilities of $P$. aeruginosa strain PA01 [66], but not of strain PA14 using our swarming conditions (data not shown). It was also reported that $g \operatorname{lm} R$ $(g l p R)$ shows increased expression during twitchingmediated chemotaxis towards phosphatidylethanolamine [67]. The ECF sigma factor-putative anti-sigma factor couple PA2895-96 was identified to have a role in the secretion of exoproteases [25], and might be under iron regulation [68]. ECF sigma factors encoded by PA1300, PA1912 and fiuI, the latter along with its related antisigma factor coding fiuR [69], are up-regulated by iron starvation [59,70]. Again, the down-regulation of these genes in tip cells indicates they are under an iron-replete environment.

\section{Genes up-regulated in the swarm center}

A substantial number of genes were highly up-regulated in swarm center (most with $\log _{2}$-fold $>3$ ) compared to the non-swarming control. Among the three conditions tested in this study, the comparison between swarm center and non-swarming displays the least expression differences, as shown by the low category $\%$ of differentially expressed genes (Figure. 1; blue bars). This suggests that these two conditions display a more similar biological status (i.e. as opposed to tendril tip vs. non-swarming and tendril tip vs. swarm center). However, as reported in table 4, the few swarm center genes considered in our analysis were on average much more highly differentially expressed (i.e. average $\log _{2}$-fold change $>3.5$ ).

P. aeruginosa codes for three different catalases. KatA is the major catalase which is highly expressed in all phases of growth [71]. KatB is detectable when induced by peroxide or paraquat [72]. The KatE (aka KatC) catalase is high-temperature inducible [73]. However its function is unclear as it does not contribute significantly to protection against oxidative stress and high osmolarity, or to virulence, under standard laboratory conditions [74][375]. Both katA and katB were strongly induced in the swarm center vs. non-swarming conditions (Table $4)$. In contrast, the catalase-encoding gene katE was down-regulated in swarming tendril tip cells (Table 3). Furthermore, alkyl hydroperoxide reductase AhpF, the thioredoxin reductase $2(\operatorname{trxB2})$ and PA3237 were also up-regulated in swarm center. The latter codes for a predicted protein of about $8 \mathrm{kDa}$ with an export signal. Along with $k a t A$ and $k a t B$, these three genes are among the more strongly induced genes by $\mathrm{H}_{2} \mathrm{O}_{2}$ exposure [75], clearly suggesting the occurrence of such stress in the center of a swarming colony. Finally, the expression of PA3287 was also reported to be induced by $\mathrm{H}_{2} \mathrm{O}_{2}$ [76]. This gene shares high similarity with ankyrin. Interestingly, AnkB, an ankyrin-like protein, is needed for optimal KatB activity [77].

Many genes associated with the copper stress response (mexP, cueA, PA3519-20) [78] were highly up-regulated in the swarm center population. These genes are part of a small subset of genes reported to be directly regulated by CueR, a transcriptional regulator central to copper resistance in $P$. aeruginosa [79]. While copper is an important element in cellular metabolism, $\mathrm{Cu}^{2+}$ was shown to accumulate in the EPS matrix of biofilms and to be particularly toxic to them [80], especially when applied in synergy with biocides [81]. This could explain in part the observed $\mathrm{Cu}$ stress response observed in swarm center bacteria.

Both the gluconate permease and the glucose $A B C$ transporter encoded by gltKGF [41] were up-regulated in swarm center. We speculate that swarm center cells are living in a glucose-depleted environment and that these systems are needed for a more efficient carbon acquisition. Here, it is important to note that while $p q q$ (PA1985-89) and $g c d$ (PA2290) genes were down-regulated in tip cells, they were "normally" expressed both in swarm center and non-swarming conditions. Thus, the oxidative pathway of glucose utilisation is not down-regulated in the swarm center, presumably because enough oxygen is available to cells in this condition.

\section{Tendril tip and swarm center bacteria constitute two distinct populations}

Altogether, our results show that there is a global shutdown of transcripts associated with known virulence factors in swarming tendril tip bacteria (including $\operatorname{lec} A$, toxA, aprA, las $A, \operatorname{rhlAB}$, rhlC, pchFEDCBA, pvdH, $p v d L G)$. Swarm center and non-swarming control bacteria show a similar expression level for virulence-related 
genes (Table 3). Importantly, the up-regulating element common to all these factors is iron-restricted conditions, indicating that the iron-replete environment encountered by actively swarming cells explains, at least in part, their reduced expression of virulence determinants. At the same time, swarming tendril cells displayed high expression of genes associated with energy synthesis (e.g. atpCDGAHFEBI, and various cytochrome $c$ oxidase subunits), and protein synthesis (ribomosal proteins, translation factors). Therefore, swarming cells at the tip of actively migrating tendrils are highly metabolically active cells that have reduced requirements for competition and nutrition acquisition factors.

A number of the down-regulated virulence factors in swarming tendril tip bacteria are also quorum sensingcontrolled. Multicellular behaviour and cell-to-cell communication are often linked [3,82-84]. However, our results clearly show that nutritional factors, here especially iron, are key elements in the regulation of swarming motility; in contrast, we do not see a clear correlation with cell density. This agrees very well with the emerging concept that quorum sensing regulation cannot be separated from environmental factors, especially availability of nutrients $[4,15,85]$.

$\mathrm{H}_{2} \mathrm{O}_{2}$ is generated during aerobic metabolism and is capable of damaging critical biomolecules. $\mathrm{H}_{2} \mathrm{O}_{2}$ production in bacteria usually mostly results from by-products of electron chain transport [86]. Our data however shows that only one gene belonging to that category, PA4133 encoding for a cytochrome $c$ subunit, was up-regulated in swarm center. At the moment, it is not completely clear why oxidative stress response genes were up-regulated in swarm center and not in tendril tips where there is apparently a higher respiration activity. One possible explanation is the preferred glucose uptake and utilisation route taken by swarm tendril tip cells. Indeed, our data indicate that these cells preferentially use the phosphorylative instead of the oxidative pathway. Possibly, the latter generates more reactive oxygen species (ROS) that are dissimilated by superoxide dismutase (SOD) to generate $\mathrm{H}_{2} \mathrm{O}_{2}$. However, this explanation is only partial as it does not clarify why swarm center cells are different in this respect from cells of non-swarming colonies. We therefore advance another explanation integrating the observed oxidative and copper stress responses occurring in swarm center populations. $\mathrm{H}_{2} \mathrm{O}_{2}$ is a normal byproduct of oxidative metabolism and naturally reacts with reduced metal ions such $\mathrm{Cu}^{2+} / \mathrm{Cu}^{+}$to produce $\mathrm{OH}^{*} / \mathrm{OOH}^{*}$ via the Haber-Weiss (aka Fenton-type) reaction $[87,88]$, a strong oxidant well known to react with and damage biomolecules [89]. In our particular case, the input of $\mathrm{Cu}$ cations has to be coming from somewhere else than the impoverished medium on which swarm center bacteria lives. As reported in several studies, dead cells constitute an important component of a microbial biofilm [90-93]. More recently, Chang \& Halverson (2009) reported a correlation between cell death and endogenous ROS accumulation in P. putida biofilms [94]. We propose that swarm center population comprises an important proportion of dead cells as is the case in $P$. aeruginosa biofilms (see additional file 6 for data supporting this hypothesis). These dead bacteria constitute an important reservoir of nutrient and metal species (such as $\mathrm{Cu}$ cations) diffusing into the live cells environment (reviewed in Harrison et al, (2007) [95]) and reacting with surrounding $\mathrm{H}_{2} \mathrm{O}_{2}$ to produce $\mathrm{OH}^{*} / \mathrm{OOH}^{*}$ and therefore triggering an important oxidative stress. Catalase is also a heme containing redox enzyme and extreme iron limitation could prevent its normal function, thus possibly playing a role in the observed oxidative stress response.

There are important divergences between our transcriptomic data and the one presented by Overhage $e t$ al., (2008). This is likely explained mostly by the difference in our respective experimental designs, as they chose to compare their swarm tip bacteria against broth cultured bacteria. In our microarray experiment, swarm center and swarm tip bacteria were compared to a control colony grown on the same media solidified for a slightly longer drying period, thus avoiding gene expression differences specific to the surface vs. broth lifestyles. In consequence, both of our studies are not readily comparable. One possible explanation for their report of up-regulation of virulence factors in swarming colonies may be related to our observation that absence of restriction to growth results in diminished expression of virulence and colonization factors, such as extracellular proteases and siderophores. Differences in respective swarm plate media (M9DCAA vs. BM2) could also account for some of the observed differences.

In figure 3, we introduce a model in which we illustrate a swarming colony dynamics model in light of our data. We propose that tendril tip cells are specialized in colonization of pristine areas. Since these areas are free of other bacteria, subpopulations of bacteria whose task is to actually colonize do not need to express virulence/competition determinants. In such a model, their main task would be to rapidly spread from their inoculating point to appropriate immediate surrounding areas as fast as possible, leaving the duty of permanent colonization to swarm center bacteria who are expressing virulence factors and survival determinants. This model underscores the labour division and bacterial multicellularity of a swarming colony. Different subpopulations in the very same bacterial colony are an efficient way for a bacterial species to consolidate its control over an area. 


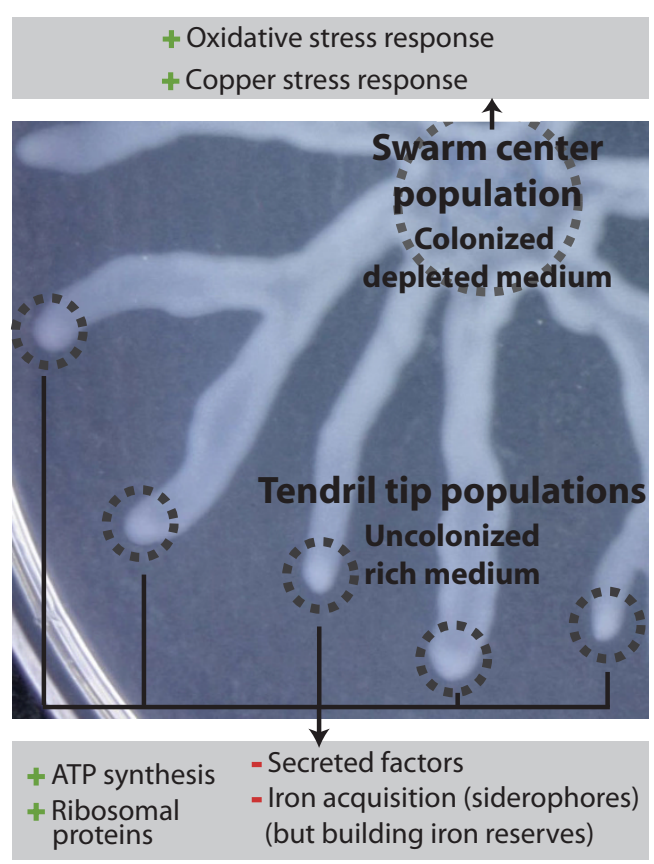

Figure 3 Proposed model of the transcriptional dynamics displayed in tendril tips and swarm center of a P. aeruginosa swarming colony. Tendril tip cells display an up-regulation of transcripts associated with energy production (ATP synthesis and cytochromes) and ribosomal proteins. At the same time, these cells down-regulate transcription associated with secreted factors (aka virulence factors) and iron acquisition. In contrast, swarm center cells live in a state in which oxidative and copper stress response transcripts are up-regulated.

\section{Conclusions}

Besides the fact that $P$. aeruginosa absolutely needs a functional flagella, a low surface-tension medium and the production of rhamnolipids, very little is known about the regulatory features of swarming motility. In the present study, we report genes that are specifically expressed in swarm center or tendril tip populations of swarming colonies. We found that cells migrating at the tip of swarming tendrils are vigorously active as shown by the up-regulation of many genes involved in the electron respiratory chain transport and ATP production. In contrast, cells remaining in the center of the swarming colony express striking oxidative and copper stress responses. Compared to tendril tips, they also produce high amounts of transcripts of many secreted factors associated with virulence and iron acquisition. Iron and, more generally, nutrient acquisition genes were actually revealed to be a central aspect in our transcriptomic analysis.

We introduced a model in which labour division is an integral part of a swarming colony dynamics. This model reinforces the idea that swarming motility is essentially used by bacteria to colonize available nutrient-rich areas. We propose that $P$. aeruginosa swarming motility in itself is not a virulent behaviour, but rather an opportunity by a colony to rapidly spread and take control of a maximum of space thanks to swarm front's metabolically active (and fast moving) cells. Finally, our data suggest that the swarm center cells establish a more stable colony displaying a biofilm-like behaviour.

\section{Additional material}

Additional file 1: Swarming motility video clip. Movie clip of Pseudomonas aeruginosa PA14 swarming motility on M9DCAA medium solidified with $0.5 \%$ agar. The plate was incubated at $30^{\circ} \mathrm{C}$. Video clip was constructed by assembling images taken every 3 minutes over a period of $21 \mathrm{hrs}$. and $45 \mathrm{~min}$. with a Canon 10D camera equipped with a Canon Ultrasonic 28-80 $\mathrm{mm}$ lens.

Additional file 2: Differentially expressed genes of tendril tip, swarm center and non-swarming bacterial populations. The complete list of genes differentially regulated in $\log _{2}$ fold-change with a $p$-value of 0.05 or lower.

Additional file 3: List of primers used in the qRT-PCR experiments Complete lists of primers used in the qRT-PCR experiments, including primer sequences are shown.

Additional file 4: Venn diagram representing differentially expressed genes for each conditions and possible combinations. Genes in each categories (A to G) are listed in additional file \#2 (excel file) under the "summary" tab. $(\uparrow)$ up-regulated genes; $(\downarrow)$ downregulated genes. Group A: 58 genes up- and 134 down-regulated in tendril tip vs. non-swarming. Group B: 16 genes up- and 3 downregulated in swarm center vs. non-swarming. Group C: 4 genes up- and 22 down-regulated in tendril tip vs. swarm center. Group D: 2 genes upand 27 down-regulated in tendril tip vs. non-swarming and swarm center vs. non-swarming. Group E: 15 genes up- and 59 down-regulated in tendril tip vs. non-swarming and tendril tip vs. swarm center. Group F: *25 genes are down-regulated in tendril tip vs. swarm center while being up-regulated in swarm center vs. non-swarming control. Group G: 13 genes are down-regulated in tendril tip vs. non-swarming, tendril tip vs. swarm center and swarm center vs. non-swarming.

Additional file 5: Flagella observations. Typical images of bacterial cells isolated from tendril tip, swarm center and non-swarming conditions. The flagella staining procedure was performed as described by Merritt and coworkers [96].

Additional file 6: Swarm center population contains more dead cells than non-swarming bacteria. Swarming and non-swarming colonies were grown as described in material and methods. For each conditions (swarm center and non-swarming), ten circular agar plugs of $0.75 \mathrm{~cm}$ diameter containing swarm center and non-swarming bacteria were extracted from plates and vigorously resuspended in $2 \mathrm{~mL}$ of sterile PBS buffer and serially diluted. For CFU count, $100 \mu \mathrm{L}$ of each serial dilution was plated on TSB agar plates and incubated $\mathrm{O} / \mathrm{N}$ at $37^{\circ} \mathrm{C}$. To determine the dry weight, the remaining bacterial suspensions were placed in pre-weighed aluminum cups and incubated at $65^{\circ} \mathrm{C}$ for $4 \mathrm{hrs}$ to allow water evaporation. Cups were weighed again to determine total dry weight. All experiments were performed in triplicates.

\section{Aknowledgements}

This study was supported by Natural Sciences and Engineering Research Council of Canada (NSERC) Discovery Grant No. 312478 to ED. JT was recipient of Ph.D. scholarships from the Fonds de la Recherche en Nature et Technologies (FQRNT) and from the Fondation Armand-Frappier. We thank David-Alexandre Fauvelle for useful comments.

\section{Authors' contributions}

$\mathrm{JT}$ designed and performed the transcript profiling and $\mathrm{qRT}-\mathrm{PCR}$ experiments and carried out downstream data analysis. ED participated in 
the conception and supervised the design of the study, and performed data analysis. JT and ED wrote the manuscript. Both authors read and approved the final manuscript

Received: 18 June 2010 Accepted: 20 October 2010 Published: 20 October 2010

\section{References}

1. Fraser GM, Hughes C: Swarming motility. Curr Opin Microbiol 1999, 2(6):630-635.

2. Harshey RM: Bees aren't the only ones: swarming in gram-negative bacteria. Mol Microbiol 1994, 13(3):389-394.

3. Kohler T, Curty LK, Barja F, van Delden C, Pechere JC: Swarming of Pseudomonas aeruginosa is dependent on cell-to-cell signaling and requires flagella and pili. J Bacteriol 2000, 182(21):5990-5996.

4. Déziel É, Lépine $F$, Milot $S$, Villemur R: rhlA is required for the production of a novel biosurfactant promoting swarming motility in Pseudomonas aeruginosa: 3-(3-hydroxyalkanoyloxy) alkanoic acids (HAAs), the precursors of rhamnolipids. Microbiology 2003, 149:2005-2013.

5. Caiazza NC, Shanks RMQ, OToole GA: Rhamnolipids Modulate Swarming Motility Patterns of Pseudomonas aeruginosa. Journal of Bacteriology 2005, 187(21):7351-7361.

6. Tremblay J, Richardson A-P, Lépine F, Déziel É: Self-produced extracellular stimuli modulate the Pseudomonas aeruginosa swarming motility behaviour. Environ Microbiol 2007, 9(10):2622-2630.

7. Davey ME, Caiazza NC, OToole GA: Rhamnolipid surfactant production affects biofilm architecture in Pseudomonas aeruginosa PAO1. J Bacteriol 2003, 185(3):1027-1036.

8. Boles B, Thoendel M, Singh P: Rhamnolipids mediate detachment of Pseudomonas aeruginosa from biofilms. Molecular Microbiology 2005, 57(5):1210-1223.

9. Pamp SJ, Tolker-Nielsen T: Multiple roles of biosurfactants in structural biofilm development by Pseudomonas aeruginosa. J Bacteriol 2007, 189(6):2531-2539.

10. Lai S, Tremblay J, Deziel E: Swarming motility: a multicellular behaviour conferring antimicrobial resistance. Environ Microbiol 2009, 11(1):126-136.

11. Butler MT, Wang Q, Harshey RM: Cell density and mobility protect swarming bacteria against antibiotics. Proc Natl Acad Sci USA 107(8):3776-3781.

12. Merritt JH, Brothers KM, Kuchma SL, OToole GA: SadC reciprocally influences biofilm formation and swarming motility via modulation of exopolysaccharide production and flagellar function. J Bacteriol 2007, 189(22):8154-8164.

13. Caiazza NC, Merritt JH, Brothers KM, OToole GA: Inverse regulation of biofilm formation and swarming motility by Pseudomonas aeruginosa PA14. J Bacteriol 2007, 189(9):3603-3612.

14. Kuchma SL, Brothers KM, Merritt JH, Liberati NT, Ausubel FM, O'Toole GA: BifA, a cyclic-Di-GMP phosphodiesterase, inversely regulates biofilm formation and swarming motility by Pseudomonas aeruginosa PA14. J Bacteriol 2007, 189(22):8165-8178.

15. Shrout JD, Chopp DL, Just CL, Hentzer M, Givskov M, Parsek MR: The impact of quorum sensing and swarming motility on Pseudomonas aeruginosa biofilm formation is nutritionally conditional. Mol Microbiol 2006, 62(5):1264-1277.

16. Overhage J, Bains M, Brazas MD, Hancock RE: Swarming of Pseudomonas aeruginosa is a complex adaptation leading to increased production of virulence factors and antibiotic resistance. J Bacteriol 2008, 190(8):2671-2679.

17. Wang Q, Frye JG, McClelland M, Harshey RM: Gene expression patterns during swarming in Salmonella typhimurium : genes specific to surface growth and putative new motility and pathogenicity genes. Molecular Microbiology 2006, 52(1):169-197.

18. Nogales J, Dominguez-Ferreras A, Amaya-Gomez CV, van Dillewijn P, Cuellar V, Sanjuan J, Olivares J, Soto MJ: Transcriptome profiling of a Sinorhizobium meliloti fadD mutant reveals the role of rhizobactin 1021 biosynthesis and regulation genes in the control of swarming. BMC Genomics 11:157.

19. Pearson MM, Rasko DA, Smith SN, Mobley HL: Transcriptome of swarming Proteus mirabilis. Infect Immun 78(6):2834-2845.

20. Tremblay J, Deziel E: Improving the reproducibility of Pseudomonas aeruginosa swarming motility assays. J Basic Microbiol 2008, 48(6):509-515.
21. Irizarry RA, Bolstad BM, Collin F, Cope LM, Hobbs B, Speed TP: Summaries of Affymetrix GeneChip probe level data. Nucleic Acids Res 2003, 31(4):e15.

22. Blazejczyk M, Miron M, Nadon R: FlexArray: A statistical data analysis software for gene expression microarrays. 2007 [http://www. gqinnovationcenter.com/services/bioinformatics/flexarray/index.aspx?l=e], (Genome Quebec, Montreal, Canada).

23. Winsor GL, Van Rossum T, Lo R, Khaira B, Whiteside MD, Hancock RE, Brinkman FS: Pseudomonas Genome Database: facilitating user-friendly, comprehensive comparisons of microbial genomes. Nucleic Acids Res 2009, 37(Database):D483-488.

24. Livak KJ, Schmittgen TD: Analysis of relative gene expression data using real-time quantitative PCR and the 2(-Delta Delta C(T)) Method. Methods 2001, 25(4):402-408.

25. Potvin E, Lehoux DE, Kukavica-lbrulj I, Richard KL, Sanschagrin F, Lau GW, Levesque RC: In vivo functional genomics of Pseudomonas aeruginosa for high-throughput screening of new virulence factors and antibacterial targets. Environ Microbiol 2003, 5(12):1294-1308.

26. Overhage J, Lewenza S, Marr AK, Hancock RE: Identification of genes involved in swarming motility using a Pseudomonas aeruginosa PAO1 mini-Tn5-lux mutant library. J Bacteriol 2007, 189(5):2164-2169.

27. Yeung AT, Torfs EC, Jamshidi F, Bains M, Wiegand I, Hancock RE, Overhage J: Swarming of Pseudomonas aeruginosa is controlled by a broad spectrum of transcriptional regulators, including MetR. J Bacteriol 2009, 191(18):5592-5602.

28. Pitcher RS, Watmough NJ: The bacterial cytochrome cbb3 oxidases. Biochim Biophys Acta 2004, 1655(1-3):388-399.

29. Williams HD, Zlosnik JE, Ryall B: Oxygen, cyanide and energy generation in the cystic fibrosis pathogen Pseudomonas aeruginosa. Adv Microb Physiol 2007, 52:1-71.

30. Shapleigh JP, Hill JJ, Alben JO, Gennis RB: Spectroscopic and genetic evidence for two heme-Cu-containing oxidases in Rhodobacter sphaeroides. J Bacteriol 1992, 174(7):2338-2343.

31. Comolli JC, Donohue TJ: Differences in two Pseudomonas aeruginosa cbb3 cytochrome oxidases. Mol Microbiol 2004, 51(4):1193-1203.

32. Kawakami T, Kuroki M, Ishii M, Igarashi Y, Arai H: Differential expression of multiple terminal oxidases for aerobic respiration in Pseudomonas aeruginosa. Environ Microbiol 2009.

33. Semrad K, Green R, Schroeder R: RNA chaperone activity of large ribosomal subunit proteins from Escherichia coli. RNA 2004, 10(12):1855-1860.

34. Snyder L, Champness W: Molecular genetics of bacteria. 1997, 504.

35. Andrews SC, Robinson AK, Rodriguez-Quinones F: Bacterial iron homeostasis. FEMS Microbiol Rev 2003, 27(2-3):215-237.

36. Chasteen ND: Ferritin. Uptake, storage, and release of iron. Met lons Biol Syst 1998, 35:479-514.

37. Palma M, Worgall S, Quadri LE: Transcriptome analysis of the Pseudomonas aeruginosa response to iron. Arch Microbiol 2003, 180(5):374-379.

38. Wilderman PJ, Sowa NA, FitzGerald DJ, FitzGerald PC, Gottesman S, Ochsner UA, Vasil ML: Identification of tandem duplicate regulatory small RNAs in Pseudomonas aeruginosa involved in iron homeostasis. Proc Natl Acad Sci USA 2004, 101(26):9792-9797.

39. Wood JM: Proline porters effect the utilization of proline as nutrient or osmoprotectant for bacteria. J Membr Biol 1988, 106(3):183-202.

40. Meile L, Leisinger T: Purification and properties of the bifunctional proline dehydrogenase/1-pyrroline-5-carboxylate dehydrogenase from Pseudomonas aeruginosa. Eur J Biochem 1982, 129(1):67-75.

41. Adewoye LO, Worobec EA: Identification and characterization of the $g / t K$ gene encoding a membrane-associated glucose transport protein of Pseudomonas aeruginosa. Gene 2000, 253(2):323-330.

42. Arkowitz RA, Wickner W: SecD and SecF are required for the proton electrochemical gradient stimulation of preprotein translocation. EMBO J 1994, 13(4):954-963.

43. Nouwen N, Driessen AJ: SecDFyajC forms a heterotetrameric complex with YidC. Mol Microbiol 2002, 44(5):1397-1405.

44. Van der Laan M, Urbanus ML, Ten Hagen-Jongman CM, Nouwen N, Oudega B, Harms N, Driessen AJ, Luirink J: A conserved function of YidC in the biogenesis of respiratory chain complexes. Proc Natl Acad Sci USA 2003, 100(10):5801-5806.

45. Schuster M, Hawkins AC, Harwood CS, Greenberg EP: The Pseudomonas aeruginosa RpoS regulon and its relationship to quorum sensing. $\mathrm{Mol}$ Microbiol 2004, 51(4):973-985. 
46. Rucker R, Chowanadisai W, Nakano M: Potential physiological importance of pyrroloquinoline quinone. Altern Med Rev 2009, 14(3):268-277.

47. Matsushita K, Toyama H, Yamada M, Adachi O: Quinoproteins: structure, function, and biotechnological applications. Appl Microbiol Biotechnol 2002, 58(1):13-22.

48. Hunt JC, Phibbs PV Jr: Regulation of alternate peripheral pathways of glucose catabolism during aerobic and anaerobic growth of Pseudomonas aeruginosa. J Bacteriol 1983, 154(2):793-802.

49. Bardy SL, Maddock JR: Polar localization of a soluble methyl-accepting protein of Pseudomonas aeruginosa. J Bacteriol 2005, 187(22):7840-7844.

50. Lyczak JB, Cannon CL, Pier GB: Establishment of Pseudomonas aeruginosa infection: lessons from a versatile opportunist. Microbes Infect 2000, 2(9):1051-1060.

51. Cox CD, Adams P: Siderophore activity of pyoverdin for Pseudomonas aeruginosa. Infect Immun 1985, 48(1):130-138.

52. Cox CD, Graham R: Isolation of an iron-binding compound from Pseudomonas aeruginosa. J Bacteriol 1979, 137(1):357-364.

53. Poole KC, Dean D, Heinrichs S, Neshat K, Krebs L, Young, Kilburn L: Siderophore-mediated iron transport in Pseudomonas aeruginosa.Edited by: Nakazawa T. Molecular biology of Pseudomonas American Society for Microbiology, Washington, DC; 1996:371-383.

54. Cobessi D, Celia H, Pattus F: Crystal structure at high resolution of ferricpyochelin and its membrane receptor FptA from Pseudomonas aeruginosa. J Mol Biol 2005, 352(4):893-904.

55. Schalk IJ, Hennard C, Dugave C, Poole K, Abdallah MA, Pattus F: Iron-free pyoverdin binds to its outer membrane receptor FpvA in Pseudomonas aeruginosa: a new mechanism for membrane iron transport. $\mathrm{Mol}$ Microbiol 2001, 39(2):351-360.

56. Braud A, Hannauer M, Mislin GL, Schalk IJ: The Pseudomonas aeruginosa pyochelin-iron uptake pathway and its metal specificity. J Bacteriol 2009, 191(11):3517-3525.

57. Goldberg JB, Ohman DE: Activation of an elastase precursor by the lasA gene product of Pseudomonas aeruginosa. J Bacteriol 1987, 169(10):4532-4539.

58. Cahan R, Axelrad I, Safrin M, Ohman DE, Kessler E: A secreted aminopeptidase of Pseudomonas aeruginosa. Identification, primary structure, and relationship to other aminopeptidases. J Biol Chem 2001, 276(47):43645-43652

59. Ochsner UA, Wilderman PJ, Vasil Al, Vasil ML: GeneChip expression analysis of the iron starvation response in Pseudomonas aeruginosa: identification of novel pyoverdine biosynthesis genes. Mol Microbiol 2002, 45(5):1277-1287.

60. Swanson BL, Colmer JA, Hamood AN: The Pseudomonas aeruginosa exotoxin A regulatory gene, $p t x S$ : evidence for negative autoregulation. J Bacteriol 1999, 181(16):4890-4895.

61. Westfall LW, Luna AM, San Francisco M, Diggle SP, Worrall KE, Williams P, Camara M, Hamood AN: The Pseudomonas aeruginosa global regulator MvaT specifically binds to the $p t x S$ upstream region and enhances $p t x S$ expression. Microbiology 2004, 150(Pt 11):3797-3806.

62. Vasil ML, Ochsner UA: The response of Pseudomonas aeruginosa to iron: genetics, biochemistry and virulence. Mol Microbiol 1999, 34(3):399-413.

63. Hamood AN, Griswold JA, Duhan CM: Production of extracellular virulence factors by Pseudomonas aeruginosa isolates obtained from tracheal, urinary tract, and wound infections. J Surg Res 1996, 61(2):425-432.

64. Gaines JM, Carty NL, Tiburzi F, Davinic M, Visca P, Colmer-Hamood JA, Hamood AN: Regulation of the Pseudomonas aeruginosa toxA, regA and $p t \times R$ genes by the iron-starvation sigma factor PvdS under reduced levels of oxygen. Microbiology 2007, 153(Pt 12):4219-4233.

65. Diggle SP, Stacey RE, Dodd C, Camara M, Williams P, Winzer K: The galactophilic lectin, LecA, contributes to biofilm development in Pseudomonas aeruginosa. Environ Microbiol 2006, 8(6):1095-1104.

66. Ramos-Aires J, Plesiat P, Kocjancic-Curty L, Kohler T: Selection of an antibiotic-hypersusceptible mutant of Pseudomonas aeruginosa: identification of the GlmR transcriptional regulator. Antimicrob Agents Chemother 2004, 48(3):843-851.

67. Miller RM, Tomaras AP, Barker AP, Voelker DR, Chan ED, Vasil Al, Vasil ML: Pseudomonas aeruginosa twitching motility-mediated chemotaxis towards phospholipids and fatty acids: specificity and metabolic requirements. J Bacteriol 2008, 190(11):4038-4049.

68. Potvin E, Sanschagrin F, Levesque RC: Sigma factors in Pseudomonas aeruginosa. FEMS Microbiol Rev 2008, 32(1):38-55.
69. Llamas MA, Sparrius M, Kloet R, Jimenez CR, Vandenbroucke-Grauls C, Bitter W: The heterologous siderophores ferrioxamine $B$ and ferrichrome activate signaling pathways in Pseudomonas aeruginosa. J Bacteriol 2006, 188(5):1882-1891.

70. Cornelis P, Matthijs S, Van Oeffelen L: Iron uptake regulation in Pseudomonas aeruginosa. Biometals 2009, 22(1):15-22.

71. Hassett DJ, Alsabbagh E, Parvatiyar K, Howell ML, Wilmott RW, Ochsner UA: A protease-resistant catalase, KatA, released upon cell lysis during stationary phase is essential for aerobic survival of a Pseudomonas aeruginosa oxyR mutant at low cell densities. J Bacteriol 2000, 182(16):4557-4563.

72. Ochsner UA, Vasil ML, Alsabbagh E, Parvatiyar K, Hassett DJ: Role of the Pseudomonas aeruginosa oxyR-recG operon in oxidative stress defense and DNA repair: OxyR-dependent regulation of katB-ankB, ahpB, and ahpC-ahpF. J Bacteriol 2000, 182(16):4533-4544.

73. Mossialos D, Tavankar GR, Zlosnik JE, Williams HD: Defects in a quinol oxidase lead to loss of KatC catalase activity in Pseudomonas aeruginosa: KatC activity is temperature dependent and it requires an intact disulphide bond formation system. Biochem Biophys Res Commun 2006, 341(3):697-702.

74. Lee JS, Heo YJ, Lee JK, Cho YH: KatA, the major catalase, is critical for osmoprotection and virulence in Pseudomonas aeruginosa PA14. Infect Immun 2005, 73(7):4399-4403.

75. Salunkhe $P$, Topfer T, Buer J, Tummler B: Genome-wide transcriptional profiling of the steady-state response of Pseudomonas aeruginosa to hydrogen peroxide. J Bacteriol 2005, 187(8):2565-2572.

76. Palma M, DeLuca D, Worgall S, Quadri LE: Transcriptome analysis of the response of Pseudomonas aeruginosa to hydrogen peroxide. J Bacteriol 2004, 186(1):248-252.

77. Howell ML, Alsabbagh E, Ma JF, Ochsner UA, Klotz MG, Beveridge TJ, Blumenthal KM, Niederhoffer EC, Morris RE, Needham D, et al: AnkB, a periplasmic ankyrin-like protein in Pseudomonas aeruginosa, is required for optimal catalase B (KatB) activity and resistance to hydrogen peroxide. J Bacteriol 2000, 182(16):4545-4556.

78. Teitzel GM, Geddie A, De Long SK, Kirisits MJ, Whiteley M, Parsek MR: Survival and growth in the presence of elevated copper: transcriptional profiling of copper-stressed Pseudomonas aeruginosa. J Bacteriol 2006, 188(20):7242-7256

79. Thaden JT, Lory S, Gardner TS: Quorum-sensing regulation of a copper toxicity system in Pseudomonas aeruginosa. J Bacteriol 2010

80. Harrison JJ, Turner RJ, Ceri H: Persister cells, the biofilm matrix and tolerance to metal cations in biofilm and planktonic Pseudomonas aeruginosa. Environ Microbiol 2005, 7(7):981-994.

81. Harrison JJ, Turner RJ, Joo DA, Stan MA, Chan CS, Allan ND, Vrionis HA, Olson $\mathrm{ME}$, Ceri $\mathrm{H}$ : Copper and quaternary ammonium cations exert synergistic bactericidal and antibiofilm activity against Pseudomonas aeruginosa. Antimicrob Agents Chemother 2008, 52(8):2870-2881.

82. Davies DG, Parsek MR, Pearson JP, Iglewski BH, Costerton JW, Greenberg EP The involvement of cell-to-cell signals in the development of a bacterial biofilm. Science 1998, 280(5361):295-298.

83. Daniels R, Vanderleyden J, Michiels J: Quorum sensing and swarming migration in bacteria. FEMS Microbiology Reviews 2004, 28:261-289.

84. Irie Y, Parsek MR: Quorum sensing and microbial biofilms. Curr Top Microbiol Immunol 2008, 322:67-84.

85. Nadal Jimenez P, Koch G, Papaioannou E, Wahjudi M, Krzeslak J, Coenye T, Cool RH, Quax WJ: Role of PvdQ in Pseudomonas aeruginosa virulence under iron-limiting conditions. Microbiology 156(1):49-59.

86. Gonzalez-Flecha B, Demple B: Metabolic sources of hydrogen peroxide in aerobically growing Escherichia coli. J Biol Chem 1995, 270(23):13681-13687.

87. Halliwell B: Superoxide-dependent formation of hydroxyl radicals in the presence of iron salts is a feasible source of hydroxy radicals in vivo. Biochem J 1982, 205(2):461-463.

88. Stohs SJ, Bagchi D: Oxidative mechanisms in the toxicity of metal ions. Free Radic Biol Med 1995, 18(2):321-336.

89. Pomposiello PJ, Demple B: Global adjustment of microbial physiology during free radical stress. Adv Microb Physiol 2002, 46:319-341.

90. Webb JS, Thompson LS, James S, Charlton T, Tolker-Nielsen T, Koch B, Givskov M, Kjelleberg S: Cell death in Pseudomonas aeruginosa biofilm development. J Bacteriol 2003, 185(15):4585-4592.

91. Mai-Prochnow A, Lucas-Elio P, Egan S, Thomas T, Webb JS, SanchezAmat $A$, Kjelleberg $S$ : Hydrogen peroxide linked to lysine oxidase activity 
facilitates biofilm differentiation and dispersal in several gram-negative bacteria. J Bacteriol 2008, 190(15):5493-5501.

92. Werner E, Roe F, Bugnicourt A, Franklin MJ, Heydorn A, Molin S, Pitts B, Stewart PS: Stratified growth in Pseudomonas aeruginosa biofilms. Appl Environ Microbiol 2004, 70(10):6188-6196.

93. Ma L, Conover M, Lu H, Parsek MR, Bayles K, Wozniak DJ: Assembly and development of the Pseudomonas aeruginosa biofilm matrix. PLoS Pathog 2009, 5(3):e1000354.

94. Chang WS, Li X, Halverson LJ: Influence of water limitation on endogenous oxidative stress and cell death within unsaturated Pseudomonas putida biofilms. Environ Microbiol 2009, 11(6):1482-1492.

95. Harrison JJ, Ceri H, Turner RJ: Multimetal resistance and tolerance in microbial biofilms. Nat Rev Microbiol 2007, 5(12):928-938.

96. Merritt PM, Danhorn T, Fuqua C: Motility and chemotaxis in Agrobacterium tumefaciens surface attachment and biofilm formation. $J$ Bacteriol 2007, 189(22):8005-8014.

doi:10.1186/1471-2164-11-587

Cite this article as: Tremblay and Déziel: Gene expression in

Pseudomonas aeruginosa swarming motility. BMC Genomics 2010 11:587.

\section{Submit your next manuscript to BioMed Central} and take full advantage of:

- Convenient online submission

- Thorough peer review

- No space constraints or color figure charges

- Immediate publication on acceptance

- Inclusion in PubMed, CAS, Scopus and Google Scholar

- Research which is freely available for redistribution

Submit your manuscript at www.biomedcentral.com/submit 